\title{
The Abortion Debate and Profeminist Coalition Politics in Contemporary Turkey
}

\section{Unal Abaday, Didem}

2019

Unal Abaday, D 2019 , ' The Abortion Debate and Profeminist Coalition Politics in

Contemporary Turkey ' , Politics \& Gender , vol. 15 , no. 4 , pp. 801-825 . https://doi.org/10.1017/S1743923X180007

http://hdl.handle.net/10138/319185

https://doi.org/10.1017/S1743923X18000703

cc_by_nc_nd

acceptedVersion

Downloaded from Helda, University of Helsinki institutional repository.

This is an electronic reprint of the original article.

This reprint may differ from the original in pagination and typographic detail.

Please cite the original version. 


\title{
The Abortion Debate and Profeminist Coalition Politics in Contemporary Turkey
}

\author{
Didem Unal
}

This article presents a qualitative analysis of profeminist Islamic women public figures' discourses in the abortion debate in Turkey in 2012. The aim is to reveal the possibilities and limitations of achieving an intersectional and egalitarian profeminist collaboration on the Islamic-secular axis in contemporary Turkey. Drawing on recent feminist scholarship on coalition politics, the article exposes the fluctuations of meaning and the shifting frames of reference in these women's narratives and relates this hybrid, dynamic narrative quality to profeminist Islamic women's unique social location. It also elaborates on the blockage points in these narratives that hinder coalitional ways of thinking. Within this frame, this article suggests that in a social and political context that has witnessed a striking upsurge of antifeminist gender politics in the last decade, the building of coalitional profeminist politics beyond the Islamic-secular divide can be facilitated by shifting the focus from the apparently irreconcilable character of ideological positionings and lived experiences toward coalitional rhetorical strategies and intermediary narrative lines in profeminist subjects' accounts.

Keywords: Abortion, Turkey, Islamic-secular, coalition politics, feminist solidarity

$\mathrm{n}$ the last decade, pro-Islamist Justice and Development Party (Adalet ve
Kalkınma Partisi, AKP) rule in contemporary Turkey has cultivated a
particular gender politics that has led to significant political contestations

The author wishes to thank the Institute of Advanced Studies of Central European University and the Thyssen Stiftung. This work would not have been possible without their financial support. The author also wishes to express her gratitude to the editor and the anonymous reviewers for their useful suggestions and comments. 
over women's bodies and sexualities (Kandiyoti 2016; Korkman 2016; Yazıc1 2012). As the party's drift toward authoritarianism has accelerated since 2011, conservative gender politics has reinforced its grip on political, social, and cultural life in Turkey, resulting in a serious backlash in terms of gender equality (Acar and Altunok 2013; Ayata and Dogangun 2017). The anti-abortion initiative in 2012 that attempted to restrict abortion in line with pronatalist aims on the political agenda has been emblematic of the party's efforts to regulate women's bodies, reproductive rights, and sexualities (Altunok 2016; Frank and Çelik 2017; Korkman 2015; Ozguler and Yarar 2017; Sehlikoglu 2015; Unal and Cindoğlu 2013).

This article looks at the recent abortion debatein Turkeywith the aim of revealing the possibilities and limitations of achieving an intersectional and egalitarian profeminist collaboration on the Islamic-secular axis. Making use of the analytical tools of narrative and frame analysis, it examines what arguments, frames, and references profeminist Islamic women public figures used to articulate their unique positions during the abortion debate in 2012. It particularly pays attention to the complexities of their positions situated at a difficult borderland where two seemingly "contradictory" and "irreconcilable" lines of thinking - Islam and feminism - are put into dialogue. Drawing on Alcoff's (2006) concept of positionality as a form of situated reasoning, this article aims to explore Islamic women public figures' interpretive horizons, which provide them a ground to develop a particular frame of reference about the abortion issue. Alcoff's (2006) nonessential, historical, and relational notion of positionality suggests that situatedness makes subjects' positions contextually bound. Accordingly, this article aims to put forward intersecting identities, power relations, and thecontextual background underlying Islamic women public figures' narratives on the recent abortion debate.

The article also positions profeminist Islamic women's narratives vis-à-vis the secular feminist critique of the AKP's anti-abortion initiative and explores the interaction between different frames used by Islamic and secular women against anti-abortion discourses. The recent abortion debate in Turkey has exposed a broad spectrum of meanings attributed to women's bodies on the Islamic-secular axis. It has demonstrated that at a political moment when the polarized political atmosphere is intensifying the Islamic-secular bifurcation, the possibility of cultivating a coalitional spirit may be severely blocked by binary oppositional framing of ideologically loaded gender issues such as abortion and women's bodies. Relying on different conceptualizations of women's bodies, 
Islamic and secular women have articulated their critique of the antiabortion initiative through different framings of abortion, collective action, and women's sexualities. Yet the inability to put different positions on abortion into dialogue has prevented them from achieving frame alignment in profeminist collective action against the anti-abortion initiative.

Against this background, this article elaborates on the dialogic openings and intermediary discursive framing perspectives in Islamic women's narrative strategies, suggesting that a dialogic, self-reflexive, and selftransformative approach in the framing of a gender debate may play a key role in alleviating the seemingly "irreconcilable" character of ideological positions. It also portrays the blockage points in these narratives and underscores the key role that the politics of intersectionality plays for successful frame alignment and coalition building.

\section{ABORTION AND THE AKP'S GENDER POLITICS}

In an international speech on population and development on May 25, 2012, Turkish president Recep Tayyip Erdog ${ }^{\longleftarrow}$ an condemned abortion, strongly arguing for pronatalist policies: "I see abortion as murder ... There is no difference between killing the child in mother's womb and killing her after the birth” (Radikal 2012). Shortly after Erdog `an's remarks on abortion, Health Minister Recep Akdag announced that his ministry was drafting a law to ban or restrict abortion and added that in case of an abortion ban, babies born out of incidents of sexual assault could be protected by the state (Hüriyet Daily News 2012). The health minister also announced penalties to be imposed on hospitals that carry out elective cesarean sections.

In Turkey, abortion has been legal until the tenth week of pregnancy since 1983, with further extensions in cases of medical conditions. The AKP's anti-abortion bill initially planned to curb the time limit for abortions, requiring all abortions to take place within the first six weeks of pregnancy. In practice, this time limit would introduce a de facto ban on abortion, effectively outlawing the right to abortion. Yet, faced with a massive public uproar and strong criticisms from the women's movement and the European Union, the government had to back away from its initial plan to curb women's access to abortion. Although the antiabortion initiative did not become codified, the proliferation of the anti-abortion stance in public discourse has led to de facto limitations 
marginalizing abortion and making it difficult for women to access safe abortion services. Moreover, the new public health law introduced in 2012 imposed a ban on c-sections, restricting them to strict medical reasons (Ayata and Dogangun 2017).

The AKP's anti-abortion initiative can be regarded as a central part of the current conservative gender regime, which derives its momentum from a nationalist, neoliberal, pro-Islamist, antifeminist, and authoritarian political vision. The nationalist connotations of the AKP's anti-abortion stance can be clearly detected in Erdog an's call urging married couples to have "at least three children." Stressing the need for a young population, he calls birth control "treason to the nation" (Hïrriyet Daily News 2013a). Reiterating his call for "at least three children" on different occasions (Hïriyet Daily News 2013b), he links the AKP's conservative politics of family and its pronatalism to the neoliberal and nationalist components of the party's rule and generates a complex patchwork in which nationalist sentiments, religious sensitivities, antifeminist politics, and neoliberal market rationality come together, reinforcing the hegemony of the AKP's political rule (Acar and Altunok 2013; Ayata and Dogangun 2017; Cindoğlu and Unal 2017; Coşar and Yeğenoğlu 2011).

In an attempt to strengthen family unity through a pronatalist vision, the AKP's pro-family gender politics replaces the principle of gender equality with the Islamic idea of equity, that is, fitrat, which intrinsically associates women with motherhood, care providing, and compassion. The concept of fitrat enables the party to position the idea of gender equality and the Islamic conception of equity in a binary oppositional relationship and to clearly distance itself from feminism. As a result, the interpretation of feminism as a Western construct with an antimotherhood and anti-religion perspective emerges as a recurrent narrative line in the AKP's conservative gender politics. Another crucial

aspect of the AKP's attempts to reinforce the hegemony of its conservative gender politics is to restrict women's activism to governmentapproved nongovernmental organizations that act in accordance with the current antifeminist gender policy perspective. Women's organizations known for their ardent support for the AKP, such as KADEM (Women and Democracy Association), play a major role in circulating the AKP's gender terminology and its gender-complementarity perspectivethrough their "docile" activism (Kandiyoti 2016).

Against this backdrop, the question of the extent to which and through what kind of narrative strategies profeminist Islamic women can voice their dissent to challenge the AKP's vision of “docile” women's activism 
and "ideal" femininity is worth paying attention to. To tackle this question, this article maps out the discursive boundaries of profeminist Islamic women's critique of the recent anti-abortion initiative and attempts to expose how this unique, multilayered critique contributes to or blocks the building of profeminist coalition politics in the contemporary Turkish context.

\section{AUTHORITARIAN REGIMES, COALITIONAL IDENTITIES}

Recently, social movement scholars have increasingly shifted the focus from context-dependent understandings of social movements to the study of movement-movement interaction (Goodwin and Jasper 2004, 2011; Whittier 2014, 2018). In this perspective, political opportunity structures that generate favorable conditions for social movements to flourishare not seen as independent variables that operate in a vacuum. Rather, what protestors and contenders make of political opportunities and the way in which they interpret the existing political conditions are equally important since their agencies cannot be reduced to structures (Goodwin and Jasper 2011). Viewing political context in a more dynamic, less structural way, this approach to social movements pays particular attention to the interaction between social movements and processes of bridge building through which activists attempt to resolve conflicts and bring different collective identities around shared goals. Following this perspective, this article aims to shift the focus from the political closures in the new gender climate in Turkey to bridge-building processes and coalition formation among women on the Islamic-secular axis.

Successful coalition building and frame alignment depend on whether collectivities engage with political intersectionality rather than relying on reified group identities (Cole 2008; Verloo 2013). Carastathis (2013) suggests that intersectionality in collective action refers tocoalition politics beyond essentialized identity categories. In this view, coalitional profeminist politics implies a shift of focus from the fixity of identity labels to contingent, issue-based cooperation informed by selftransformation, dialogue, and cultivation of sympathy for others' needs (Hewitt 2011; Lyshaug 2006). This stress on the transformative, relational character of coalitions challenges the idea that coalitions attribute fixity and uniformity to coalitional political activities (Mohanty 2003; Weir 2008). When defined in these terms, coalition politics can become a way of indicating that it is possible to come up with an understanding of 
identity politics that does not erase differences and also acknowledges entangled belongings (Anzaldúa 2002; Keating 2005; Lugones 2003).

In contexts marked by a close alliance between patriarchy and authoritarianism, recognition of the politics of intersectionality in collective action becomes even more critical, since reclaiming progressive feminist values against the authoritarian, patriarchal gender regime requires redefining them through an expansive, anti-hierarchical, and egalitarian understanding (Fraser 2016; Moghadam and Gheytanchi 2010). The recent abortion debate in the Turkish context clearly demonstrates that successful coalition building depends on whether collectivities can engage in intersectional, self-transformative interaction beyond reified identity positions. To further reflect on this, this article operationalizes the following questions as a guideline in this study: In what ways does the current political moment in Turkey incite profeminist subjects to seek new collaborative frameworks and egalitarian discourses in the struggle against the alignment of patriarchy and authoritarianism? What are the implications of this new political momentum for the Islamic-secular bifurcation among profeminist women? How can coalitional profeminist politics at the current political moment help women overcome the limitations of this bifurcation and expose the possibilities underlying it?

\section{METHOD AND CASE SELECTION}

The discussion is based on a qualitative study of Islamic women public figures' narratives on the anti-abortion initiative in Turkey in 2012. It presents an analysis of how profeminist Islamic women who are influential opinion makers as scholars, columnists, authors, and activists articulate the unique aspects of their views on abortion and formulate their critique of the prohibitionist stance on women's reproductive rights. Online versions of national newspapers with high circulations and different ideological positions are studied with a focus on the abortion debate in 2012. Accordingly, five newspapers - Radikal, Taraf, Habertürk, Yeni Şafak, and Star - are included in the study. ${ }^{1}$ The period studied covers May 2012 to July 2012, concentrating on

1. Habertürk, Yeni Şafak, and Star and are pro-government dailies declaring ardent support for the AKP's policies and political perspectives. Radikal and Taraf were newspapers with a liberal democratic orientation, but in 2016, the former was shut down because of economic difficulties, and the latter was closed under a statutory decree during the state of emergency after the 2016 coup attempt. 
profeminist Islamic women's immediate reactions to Erdogan's controversial anti-abortion speech on May 25, 2012, followed by an antiabortion initiative. Prominent Islamic women columnists' newspaper articles on the recent abortion debate are also identified and analyzed with the aim of exposing the narrative lines, framings, and rhetorical strategies underlying them. As a result, 14 newspaper articles are studied in line with the purposes of the research. Moreover, profeminist Islamic women's interviews and public statements on the abortion debate that appeared in national newspapers and online news portals between May 2012 and July 2012 are used as supplementary data. This data is supplemented with semistructured interviews that the author conducted in 2013 with four Islamic women columnists - Hidayet Şefkatli Tuksal, Nihal Bengisu Karaca, Yıldız Ramazanog $\breve{\jmath}$ lu, and Sibel Eraslan - as a part of her doctoral dissertation on feminist self-identification in contemporary Turkey. The article makes use of these interviews, focusing on the parts in which Islamic women columnists specifically commented on the recent abortion debate.

Relying on this data, the study employs the analytical tools of narrative and frame analysis with the aim of exposing how profeminist Islamic women interpret, problematize, and give meaning to the recent abortion debate and what arguments and references they use to articulate their positions. Frame analysis is useful in this study as it enables the identification of the interpretive processes that characterize engagement with a public issue. The notion of frame refers to the "interpretive schemata" used by individuals and collectivities for interpreting the social, political, and cultural world (Bacchi 2005; Benford and Snow 2000; Sutton and Borland 2013). Frames align with the beliefs, everyday experiences, and cultural understandings of individuals and collective groups (Benford and Snow 2000). They are reflective of group boundaries that are employed to establish collective identity and point out the possibilities for bridging differences among different collectivities. This study pays attention to how frames are used by profeminist Islamic women to generate a coherent narrative that reflects their unique position on the recent abortion debate.

Making use of the feminist scholarship on coalitional politics and the politics of intersectionality, this article acknowledges that identities are always open to rearticulation and change through dialogic encounters with others that render them coalitional (Carastathis 2013; Keating 2005; Lyshaug 2006; Weir 2008). In order to point out this potential for change, it employs flexible terminology in addressing the bifurcation 
between Islamic and secular women in Turkey. Drawing on previous scholarship (Akman 2013; Aldikacti-Marshall 2005; Coşar and Onbaşı 2008), this article uses the labels "secular" and "Islamic" as loose prefixes regarding religious affiliation rather than as fixed identification labels based on ready-made, predetermined values and norms. On the other hand, given that some secular and Islamic women strictly avoid the term "feminist" (Aldikacti-Marshall 2005; Coşar and Onbaşı 2008; Unal 2015), it employs the term "profeminist" with the aim of implying a broad engagement with progressive feminist values and norms. In doing so, the article aligns with recent scholarship on feminist selfidentification that emphasizes praxis and engagement with progressive values rather than identity labels and introduces a shift of focus from the stereotypical baggage of "feminist identity" to "identification with feminist values" (Budgeon 2001; Misciagno 1997; Scharff 2013).

\section{COALITIONAL SOLIDARITY ON THE ISLAMIC-SECULAR AXIS}

The recent upsurge of antifeminist gender politics in the Turkish context has incited many debates on the limits and possibilities of collaboration in the women's movement. Some scholars suggest that the political urgencies of the current gender regime provide women with opportunity structures that facilitate dialogue based on a commitment to universal rights and values and lead to profeminist alliances beyond ideological antagonisms (Onar and Paker 2012; Simga and Goker 2017). According to this view, coalition building based on strategic alliances around human rights discourse urges subjects to act in concert in the temporary pursuit of specific shared goals and ensures mutual recognition of differences.

Others point out that this cosmopolitan approach, with its right-based agenda and stress on mutual recognition of differences, tends to idealize deliberation without problematizing the power relations and hierarchies embedded in the dialogic processes and is mainly interested in reinforcing strategic alliances (Bora 2012; Coşar and Onbaşı 2008). Their critique stems from the idea that inclusive political ties can only be achieved through ethical and dispositional self-transformation (Budgeon 2015; Hewitt 2011; Lyshaug 2006). Accordingly, mutual recognition of differences may lead to a cognitive awareness of others' needs and demands, yet it does not necessarily incorporate a deeper form 
of reciprocity into the formation of feminist solidarity beyond the contingency of the political agenda.

Lyshaug (2006) contends that establishing ties of sympathy between diverse selves can help women achieve an ethically rich form of mutual recognition that supplements improved knowledge or understanding of the "other" achieved in communicative action with an ethical and dispositional self-transformation. Pointing out the perils of defining coalitional solidarity solely from within the political urgencies as a fluid and strategic alliance, she calls for a comprehensive understanding of feminist coalitional politics in which tactical strategies and a cultivation of sympathy forging inclusive political ties can coexist.

Given that differences present themselves only in communicative engagement and their unfolding through dialogue in unpredictable ways may lead to new contestations (Benhabib 1992; Dean 1997; Weir 2008), controversial gender issues highly loaded with essentialist framings of ideological positions may further complicate the processes of coalition building. At such points, attempts to reconcile different understandings of coalitional solidarity, namely, "strategic coalitions around cosmopolitan values" and "coalition as a transformative, dialogic ideal," may be easily interrupted. The recent abortion debate in Turkey is indicative of this. The apparently irreconcilable character of their ideological positionings and lived experiences have prevented secular and Islamic women from reaching an agreement on how to frame a unanimous profeminist critique against the prohibitionist stance on abortion. This article aims to shift the focus from this impasse blocking profeminist coalition building to the dialogic openings in profeminist subjects' discursive framings of the recent abortion debate in Turkey. It suggests that despite the rigidity of ideological positions and essentializing tendencies, dialogic and self-reflexive narrative lines in profeminist subjects' accounts may play a key role in preparing the ground for a coalitional way of thinking.

\section{REFORMIST COMPONENTS IN THE WOMEN'S MOVEMENT}

Since its emergence in the 1980s, the autonomous secularwomen's movement in Turkey has relied on a monolithic conception of womanhood and has limited its scope to the concerns and demands of urban, secular, middle-class women (Diner and Toktas, 2010). The transformation of the women's movement beginning in the 1990s, 
along with the rise of Islamist, Kurdish, and lesbian, gay, bisexual, and transgender movements, gave way to close collaboration between secular and Islamic profeminist women (Akman 2014; Arat 2004; Diner and Toktas, 2010; Onar and Paker 2012). In the 2000s, collaborative activist platforms such as CEDAW (Convention on the Elimination of All Forms of Discrimination Against Women) meetings; the Woman Platform for Perpetual Peace, a platform committed to opposing war and reinforcing peace in Turkey and in the broader Middle East; and the Platform for the Reform of the Turkish Civil Code and the Women's Platform for the Reform of the Turkish Penal Code, both of which are aimed at improvements in legal frameworks to ensure the full implementation of the principle of gender equality, have greatly contributed to the opening of dialogic channels in women's activism in Turkey.

The interaction between Islamic profeminist women and secular feminists has always been quite complex and multilayered in that it includes both oppositional and collaborative forms of relationship. The reformist/orthodox character of women's organizations appears to be a decisive factor that facilitates or blocks collaboration in between. It is the reformist components of the women's movement and activism that provide women activists an interpretive horizon through which they can go beyond the binary oppositional reading of Islamic and secular viewpoints and acknowledge the perils of reifying internal differences as irreconcilable traits (Arat 2016). The Capital City Women's Platform (Baskent Kadın Platformu), the Rainbow Istanbul Women's Organizations Platform (Gokkusagı Istanbul Kadın Kurulusları Platformu), and the Women's Rights Association against Discrimination (Ayrımclliga Karsi Kadın Hakları Dernegi) can be cited here as nonorthodox/reformist Islamic women's civil society organizations that deal with women's issues beyond charity work, use fundamental feminist ideas and principles in their discursive strategies, and have considerable influence on policy makers through counseling and lobbying activities (Aksoy 2015; AldikactiMarshall 2005).

Whittier $(2014,2018)$ claims that public issues that have attained political neutrality thanks to overlapping collective action frames are more likely to lead to successful bridge building and collaboration. Within this frame, in the recent era, issues such as child abuse, violence against women, and women's autonomy regarding sartorial choices have attained political neutrality in collective action and provided a common ground for Islamic and secular feminist women to reach successful 
frame alignment. The feminist initiative Birbirimize Sahip Cikiyoruz (We Are Looking After Each Other), a platform founded in 2008, is a good example of overlapping collective action frames used by Islamic and secular feminist groups against the headscarf ban (Ozcetin 2009; Saktanber and Çorbaciog lu 2008). It hinted at the potential for going beyond the dominant political discourses through consolidated frames shared by women from different ethnic, religious, and ideological backgrounds. This potential also manifested itself in feminist protests in 2017, when women rallied for the right to wear both miniskirts and headscarves, chanting slogans such as "don't meddle with my headscarf, don't meddle with my shorts" (Hürriyet 2017). ${ }^{2}$ Activists and influential public figures from both secular and Islamic camps cite these deliberative experiences as transformative points in reinforcing the dialogue in between (Onar and Paker 2012; Simga and Goker 2017). Moreover, the Recel Blog 3 has been one of the popular online portals in the recent era, where young Islamic women can discuss gender issues ranging from child sexual abuse to veiling through a gender-conscious perspective. The Initiative of Muslims Against Violence to Women can also be cited as another significant example of newly emerging profeminist activism among young Islamic women. Recognition of the politics of intersectionality, profeminist framings against male violence, and openness for shared collective action with secular feminists render this initiative a potential actor to produce frame alignment in the women's movement (Ozinanir 2016).

In a nutshell, by putting Islam and feminism into dialogue, the reformist factions of Islamic women's activism portrayed here acknowledge the significance of coalitions, dialogue, and the need to ensure an inclusive collaboration among women of different backgrounds. The voices of profeminist Islamic women that we hear in this article provide us with deep insights into this reformist section of Islamic women's activism. Although most women in this reformist section of Islamic women's activism have resentments about secular feminist movements' exclusionary agenda dating back to the 1980 s and 1990s, some prioritize inclusive collaboration over resentful thinking,

2. Another example of collaborative spirit has manifested itself in feminist reactions against AKP's recent draft law stipulating that men who sexually abuse girls under 18 without any restriction on consent and who marry their victim can go free (Agerholm 2016). In their critique of the draft law, profeminist Islamic women shared similar framings with secular feminists, articulating their dissent in online platforms, press declarations, and newspaper columns (Karaca 2016; Sonmez 2016).

3. See http://recel-blog.com/. 
while others are warier of close ties with secular feminists (Aksoy 2016; $\mathrm{Cos}_{\text {, }}$ ar and Onbas, 12008). Yet during the abortion debate in 2012, they became a unanimous group with respect to three factors: (1) their critique of AKP's anti-abortion initiative, (2) their critique of secular feminist protests against the AKP's anti-abortion initiative, and (3) their conceptualizations of a woman's body as an entrusted entity beyond individual autonomy. The next section will elaborate on the unique aspects of profeminist Islamic women public figures' positions in society, preparing the ground for a detailed analysis of their framings of the recent abortion debate.

\section{BORDERLAND POSITIONS}

Recently, Islamic profeminist women public figures have emerged as significant actors in the public sphere, aligning with secular feminists around cosmopolitan values such as access to basic human rights and dramatically influencing the framing strategies of reformist components of Islamic women's activism (Aksoy 2016; Arat 2016). They have not only challenged the orthodox secular assumptions that associate veiling with submission to patriarchy but also contested the patriarchal dynamics of Islamist politics (Eraslan 2002). Their critique of Islamist politics dates back to the 1990s, when Islamic women assumed critical roles in Islamist politics for the first time but were left out of the party cadres following the electoral victory. Under the AKP, this critique has evolved into a stronger position as a result of the party's reluctance to lift the headscarf ban in public institutions (Akman 2013; Arat 2016). Profeminist Islamic women severely criticized the party for lifting the headscarf ban only in the third term of its rule and argued that this inertia clearly points out veiled women's symbolic status in Islamist politics (Akman 2013; Arat 2016).

On the other hand, profeminist Islamic women also align with the AKP and the Islamist male elite around certain critical issues on the conservative gender agenda, affirm the party's emphasis on family as the key unit in socialization, and support its policies that provide women with flexible working hours and extended maternal leave options (Akman 2013; Arat 2016). This support may appear in the form of appraisal of the AKP's positive legal action with respect to women's employment, education, and the struggle against violence against women (Arat 2016). It may also appear as a defense of the AKP's conservative gender politics against 
secular feminists who harshly oppose it. ${ }^{4}$ From here, it is possible to suggest that profeminist Islamic women's position vis-à-vis the AKP's gender politics is quite complex and Janus-faced. This complexity stems from the fact that they situate themselves at a difficult borderland position where they attempt to put into dialogue two seemingly "contradictory" and "irreconcilable" lines of thinking, namely, Islam and feminism. Alcoff (2006) suggests that the peculiarities of one's situatedness in a social location generate a dynamic, context-specific frame of reference that informs the interpretive horizons one utilizes to negotiate identities. Using Alcoff's terminology, one can suggest that profeminist Islamist women's interpretive horizons are formed through complex processes of meaning-making from within a social location that is continuously subject to reinterpretation. Navigating multiple focus points and shifting references, they provide us with multilayered narratives that are difficult to situate in a fixed position on the Islamic-secular axis (Unal 2015). It is this complex position that makes the question of how to achieve sustainable coalitional solidarity in the women's movement even more difficult to resolve in the contemporary Turkish context. The following discussion delves into this question, portraying the shifting narrative lines and rhetorical strategies in Islamic profeminist women's narratives on the recent abortion debate.

\section{ABORTION AT THE INTERSECTION OF ISLAM AND FEMINISM}

Following Erdog `an's statement in 2012 interpreting abortion as murder and his announcement of an anti-abortion initiative, profeminist Islamic women unanimously opposed the AKP's plans to introduce a ban on abortion. They clearly stated that the anti-abortion initiative was "divisive, patriarchal, vulgar, brutal, provocative and utilitarian" (Kubilay 2014). Given that profeminist Islamic women public figures are prominent opinion leaders in the Islamic community, this unanimous stance improved the efficacy of profeminist discourses in the abortion debate and hinted at the possibility of expanding the contours of the

4. For some Islamic profeminist women, secular feminists are prone to misinterpreting the social and political effects of the AKP's gender discourses in that they treat the AKP's conservative discursive acts as legal intervention and deny the party the liberty to articulate its conservative gender policy perspective (Arman 2015; Ilter 2016). This critique implies that secular feminist activists struggling against the current proliferation of patriarchal discourses are overreacting, since discourse cannot be as "threatening" as legal intervention. 
profeminist publics toward a coalitional way of thinking beyond ideological bifurcations.

On the other hand, this optimistic reading of Islamic profeminist women's opposition to the anti-abortion initiative does not provide a comprehensive picture of the complexity of their positions in the abortion debate. To get a deeper insight into their multilayered narratives, one should engage in a nuanced analysis of the interpretive frameworks and prominent narrative themes that they employ in articulating the authenticity of their line of thinking

First of all, their narratives clearly portray their Janus-faced attempts to reconcile the religious conceptualization of abortion with a profeminist critique of the prohibitionist approach to abortion. Most of the pious women columnists and activists who publicly declared an opinion on the recent abortion debate underlined that in Islam, termination of pregnancy is considered contrary to God's will since it is believed that God entrusts the fetus to the mother. However, regardless of their disapproval of abortion on a religious basis, they openly expressed their critique of the recent anti-abortion initiative by relying on two lines of thinking. First, they framed abortion as a legitimate practice in cases of economic difficulties, sexual violation, and health emergency (Eraslan 2012a, 2012b; Karaca 2012b; Sonmez 2012). ${ }^{5}$ Second, they problematized the patriarchal male discourses in statements of AKP members of Parliament that overshadow women's needs and concerns and strategically use them for political purposes (Barbarosoğlu 2012; Böhürler 2012; Karaca 2012a, 2012b, 2012c; Ramazanoğlu 2012a; Tuksal 2012a, 2012b). Berrin Sonmez, a scholar, columnist, and activist from the Capital City Women's Platform, states:

As a Muslim, I believe that God entrusts the fetus to the woman ... It is necessary to take into account the rights of the fetus but the religious, social repercussions of this issue have to be framed as a women's issue ... Of course, abortion should not be encouraged; it can only be the last resort when the circumstances render it necessary. Yet, I find it quite harmful that future legal arrangements may deny women this last resort .. . A possible prohibition would endanger women's health. (Taraf 2012)

5. One should note that this framing is quite problematic, as it tends to define a list of "legitimate" reasons justifying women's access to abortion. It is articulated from within an Islamic line of thinking that does not engage in a meaningful conversation with the profeminist conception of women's bodily autonomy. 
This dual stress on the religious interpretation of abortion and the critique of the prohibitionist stance on abortion also resonates in the following statement of Hidayet Şefkatli Tuksal:

I am against abortion I do not see my baby as a piece of flesh in my body ... Before all, since the baby is alive, it has a right to live. However, I am against any ban on abortion because a possible ban would cause many problems for women's health and once again women would have to pay for this. (interview, April 15, 2013)

Navigating the Islamic-secular axis, Islamic profeminist women construct their narrations on an elusive ground where the reference point constantly shifts between a religious and a more secular-oriented standpoint. It is this constant negotiation between Islamic and secular lines of thinking that makes their position highly hybrid. Yet when women's autonomy over their bodies is at stake, these shifts of reference on the Islamic-secular axis, which may generate a dialogic exchange between feminism and Islam, stabilize because of the prioritization of Islam in the interpretative framework. At these points, the critique of the secular feminist stress on woman's bodily autonomy becomes the main theme of the argument, surpassing the critique of AKP's anti-abortion initiative.

\section{A WOMAN'S BODY: INDIVIDUAL PROPERTY OR ENTRUSTED ENTITY?}

The majority of the recent feminist protests against the anti-abortion initiative in 2012 were organized by secular feminists around mottos such as "it is mybody, so who areyou?" or "mybody, my decision." The framing of abortion as "women's right to decide about their bodies" and other references to bodily rights are long-standing feminist concerns that aim to disrupt patriarchal control over women's bodies and sexualities and contribute to the circulation of the notion of women's individual autonomy. Sutton and Borland (2013) demonstrate that in contexts in which notions of women's bodily autonomy do not convey the same sense of urgency as other framings, such as "abortion as an issue of public health," women activists may consider complementing the frame "women's right to their bodies" with pragmatic, strategic discourses that frame abortion with reference to health emergencies, economic difficulties, or sexual violation. This wide repertoire of radical and culturally resonant framings depends on how actors perceive political 
opportunities, construct collective identities, and define their available choices (Ferree 2003, 2009). It is widely noted that different conceptualizations of a woman's body appear as major fault lines in abortion debates, compelling activists to carefully negotiate between radical and culturally resonant framings (Kubilay 2014; Sutton and Borland 2013). Complementary and competing understandings of woman's body enter into dialogue in activists' campaigns for abortion rights, shaping the prospects for successful frame alignment and bridge building in collective action.

In the recent abortion debate in Turkey, many Islamic women public figures and activists have identified the idea of the "right to abortion" and the categorical secular feminist stress on women's bodily authority as major obstacles hindering the building of an all-inclusive coalitional standpoint in women's activism (Aktas 2012; Albayrak 2012; Böhürler 2012; Eraslan 2012b; Ramazong lu 2012b; Tuksal 2012a). Given that the Islamic line of thinking stresses the divine authority upon the body and refrains from granting bodily autonomy to the individual will (Șiş man 2006), it turns out that it is not easy to generate dialogic channels where Islam can be put into dialogue with the secular idea of women's bodily autonomy and "the right to abortion."

Tuksal (2012a) points out that the secular slogan "my body, my decision" is not receptive to pious women's sensitivities. For her, in order to ensure the broadest coalition against patriarchal policies in Turkey, secular profeminist publics should refrain from elitist, isolationist discourses and take into account multiplicities in women's demands. In a similar vein, Ylldız Ramazanog ${ }^{\smile}$ lu (2012b), a pious writer, columnist, and activist, stresses the authenticity of her position on women's embodiment in following terms:

What Ibelieveisthatourbodydoes notbelong to anybodybutisentrusted to us. For me, it is not appropriate to claim an absolute ownership over the body that we did not create; it is equally inappropriate to assume that one can use it as one wishes.

These accounts clearly put forward that different conceptualizations of a woman's body by Islamic and secular profeminist publics demand a nuanced approach to the issue of abortion that can put radical and culturally resonant framings into dialogue. On the other hand, one should also note that Islamic profeminist women's stress on the authenticity of the Islamic conceptualization of a woman's body does not necessarily reify the Islamic-secular bifurcation and hinder 
collaboration in profeministpublics. Rather, itcanberegarded as a callfor enacting a constructive dialogue about how different conceptualizations of a woman's body can be incorporated into profeminist conversations on abortion without necessarily requiring commonality between different identity positions. This call for recognition of differences can align with the coalitional spirit of the dialogic platforms in the women's movement recently generated against the rising tide of patriarchal gender politics in Turkey. Thus, it is not the articulation of authenticity per se but the lack of willingness to open the self to multiplicity that blocks the potential for self-transformation and obstructs profeminist women's dialogic attempts.

\section{COALITIONAL NARRATIVE STRATEGIES AND FRAMINGS}

Given that subjects speak from within a unique positionality, that is, a perspectival location formed as a result of the interaction with contextual dynamics (Alcoff 2006), one should keep in mind that Islamic profeminist women's frustration with the exclusionary character of secular women's activism dating back to 1980 os generates a powerful interpretive framework in their line of thinking. This interpretive framework may trigger essentialist tendencies that reproduce stereotypical framings of secular feminism as inherently exclusionary, anti-family, or anti-motherhood (Onar and Paker 2012). The recent abortion debate has further crystallized the restrictive aspects of the resentful thinking deeply embedded in Islamic profeminist women's interpretive horizons. Islamic profeminist women's association of abortion with arbitrariness, carelessness, and the strong references they make to its misuse as a birth control method, point out the blockage points in their narratives where past resentments culminating in essentialist fixations of secular feminism overshadow the dialogic incentives to foster mutual recognition.

Addressing secular feminists who protested the anti-abortion initiative by chanting the slogan "our bodies are ours," Sibel Eraslan (2012b), a novelist and columnist, states that secular feminist activism misrepresents the issue of abortion by regarding it as a matter of celebration:

There is no woman on earth who would enjoy the experience of abortion. This is especially true when women choose the option of abortion because of medical emergencies ... Abortion is all about a metal tool's cutting, evacuating your body ... Therefore, I cannot understand the festival atmosphere generated for the defense of abortion I am totally irritated by this celebratory mode and acts of undressing. 
Attempting to define the contours of the profeminist critique against the prohibitionist approaches to abortion, Eraslan disconnects the idea of abortion from individual autonomy by framing it as a traumatic experience dictated by medical emergencies and undermines the gist of embodied secular protests where a woman's body itself becomes a site of protest. The rigidity of this argumentation line and the essentialist tendencies embedded in it also appear in some other columns studied in this article. While Böhürler (2012) presents the authenticity of the Islamic conceptualization of a woman's body as a red line that pious women will never negotiate, Ramazanog lu (2012b) warns against the perils of the individualist interpretations of abortion, implying that they can easily lead to arbitrariness and carelessness.

The recent scholarship on coalitional profeminist politics points out that adopting a self-reflexive and dialogic approach can be an effective way of overcoming essentialist tendencies and stereotypical interpretations as it invites subjects to be open to others' positionings and transforms the self through moving it into an unfamiliar territory (Anzaldúa 2002; Keating 2006; Weir 2008). Within this frame, one should note that despite its limitations, the profeminist critique of the recent upsurge of antiabortion discourse in Turkey also entails certain dialogic qualities that urge activists and profeminist public figures to engage with the question as to how to frame a meaningful, inclusive, and transformative dialogue between women from different backgrounds. Criticizing the slogan "my body, my decision" through a self-reflexive approach, some secular feminists point out that the individualized notion of the self in the secular feminist discourse of "the right to abortion" abstracts women from social structures, ignores their unique positionalities in the public sphere, and precludes receptivity to different womanhood positionalities (Bora 2012). This dialogic call for revision has the potential to reinforce mutual recognition of differences and self-reflexive transformation. In a similar vein, a detailed narrative analysis puts forward that the dialogic openings in Islamic profeminist women's accounts of the abortion debate display a willingness to bridge differences and to build inclusive political ties. In her column in Yeni Şafak, Özlem Albayrak, a pious columnist, calls for a new discursive framework where secular and Islamic framings of abortion are not articulated in binary oppositional terms but are put into dialogue through constructive argumentation lines. Engaging in a dialogic attempt to understand secularprofeminist women's perspective, Cihan Aktas (2012), a pious writer and columnist, contributes to this reformist stance by refraining from essentializing the 
secular profeminist framing of abortion as the "other" of Islamic interpretations. Taking into account the contextual dynamics underlying the contemporary gender regime in Turkey, she states that the argument "my body, my decision" and the rhetoric of the right to abortion' should be regarded as a reflexive response to the vulgarity of the patriarchal statement "abortion is murder" and the ideological patchwork that frames it (Aktas 2012). A similar incentive to adopt a dialogic approach inclusive of others' perspectives also resonates in Karaca's (2012b, 2012d) columns, in which she calls for intermediary discourses beyond divisive, rigid, and unnuanced framings of abortion and states that "abortion is not an issue that one can discuss over rigid arguments."

These dialogic, relational discursive acts imply that when controversial gender issues appear on the agenda that further trigger the Islamicsecular bifurcation among women by reifying their ideological positionings and making it difficult for them to come together around cosmopolitan values, a key method to ease confrontation and facilitate a coalitional way of thinking might be to focus on the reformist narrative lines calling for flexibility, openness, and hybridity. Under the current authoritarian gender regime in Turkey, profeminist women are confronted with the difficult task of providing quick, critical responses vis-à-vis political urgencies while at the same time attempting to form sustainable political ties. The recent abortion debate in Turkey has clearly put forward that by using dialogic rhetorical strategies, women can continue to make efforts to transcend differences that block coalitional ways of thinking. From here, it is possible to suggest that especially in contexts marked by the rising tide of patriarchal discourses and increasing polarization of different womanhood positions, highlighting the role of dialogic discursive frames in constructing relations of solidarity can be quite helpful in alleviating the destructive effects of ideological confrontation. This shift of focus from the apparently irreconcilable character of ideological positionings and lived experiences toward coalitional narrative strategies can also provide scholars and activists an alternative way of looking at the Islamic-secular bifurcation in profeminist publics in contemporary Turkey.

\section{CONCLUSION}

This article has demonstrated that the recent abortion debate in Turkey has been a litmus test that has crystallized the differences in Islamic and secular 
women's conceptualizations of a woman's body. It has also highlighted the importance of the question of how to transform the Islamic-secular bifurcation in women's activism into a constructive force that can contribute to the inclusivity of contemporary profeminist struggles in Turkey. Within this frame, this article has pointed out that the possibility of collaboration increases when reformist elements of Islamic and secular profeminist publics can come together on deliberative civic platforms around common goals formulated in the light of cosmopolitan values. Yet, in a context like Turkey, where the polarized political atmosphere intensifies the Islamic-secular bifurcation, this profeminist coalitional spirit may be severely undermined by gender issues such as abortion, sexualities, and women's bodies that are strictly framed in binary oppositional terms and highly loaded with ideological baggage. As the foregoing discussion has revealed, at such moments, the building of profeminist coalition beyond the Islamic-secular divide depends on the cultivation of the dialogic, relational character of the reformist elements both in secular and Islamic profeminist publics. A dialogic understanding of coalitional solidarity that reconciles tactical political concerns with a willingness to open the self to others' perspective can serve as a panacea to the impasse generated by the rigidity of ideological positionings. This dialogic approach can be facilitated by shifting the focus from the apparently irreconcilable character of ideological positionings and lived experiences toward coalitional rhetorical strategies and intermediary narrative lines in profeminist subjects' accounts. As a result, this shift of focus might be helpful in revisiting the issue of difference in such a way as to incorporate it into a meaningful, transformative dialogue.

\section{REFERENCES}

Acar, Feride, and Gülbanu Altunok. 2013. "The 'Politics of Intimate' at the Intersection of Neo-liberalism and Neo-conservatism in Contemporary Turkey." Women's Studies International Forum 41: 14-23.

Agerholm, Harriet. 2016. “Turkey Says Child Rape Pardon Law Can Be Amended but Refuses to Withdraw It.” The Independent (London), November 22. https://www. independent.co.uk/news/world/europe/turkey akp-child-rape-law-pardon-amended-protestchp-amended-withdraw-a7430251.html (accessed October 28,2018).

Akman, Canan Aslan. 2013. "Islamic Women's Ordeal with the New Faces of Patriarchy in Power: Divergence or Convergence over Expanding Women's Citizenship.” In 
Gendered Identities: Criticizing Patriarchy in Turkey, eds. Rasim Özgür Dönmez and Fazilet Ahu Özmen. Lanham, MD: Lexington Books, 113-47.

Aksoy, Hurcan Asli. 2015. "Invigorating Democracy in Turkey: The Agency of Organized Islamist Women.” Politics \& Gender 11 (1): 146-70.

Aktas, Cihan. 2012. "Kurtajve Uludere Kolaji”[Abortion and Uludere College]. Taraf, May 31.

Albayrak, Özlem. 2012. "Kürtaj: Ya yandassin, ya katil!" [Abortion: You are either a supporter or murderer!]. Yeni SSafak, June 5.

Alcoff, Linda. 2006. Visible Identities: Race, Gender and the Self. New York: Oxford University Press.

Aldikacti-Marshall, Gul. 2005. "Ideology, Progress, and Dialogue: A Comparison of Feminist and Islamist Women's Approaches to Head Covering and Work in Turkey." Gender \& Society 19 (1): 104 -20.

Altunok, Gülbanu. 2016. "Neo-conservatism, Sovereign Power and Bio-power: Female Subjectivity in Contemporary Turkey." Research and Policy on Turkey 1 (2): $132-46$.

Anzaldúa, Gloria E. 2002. Preface to This Bridge We Call Home: Radical Visions for Transformation, eds. Gloria E. Anzaldúa and AnaLouise Keating. New York: Routledge. Arat, Yesim. 2004. "Rethinking the Political: A Feminist Journal in Turkey,Pazartesi." Women's Studies International Forum 27: 282 - 97.

-2016. "Islamist Women and Feminist Concerns in Contemporary Turkey: Prospects for Women's Rights and Solidarity.” Frontiers: A Journal of Women's Studies 37 (3): $125-50$.

Arman, Ayse. 2015. "Ilahiyetci yazar Hidayet Sefkatli Tuksal: Cocuk basina her ay $1500 \mathrm{Tl}$ Versinler" [Theology scholar Hidayet Ș efkatli Tuksal: Child support allowance should be 1500TL per child]. Hïrriyet, January 11. http://www.hurriyet.com.tr/yazarlar/aysearman/ilahiyatci-yazar-hidayet-sefkatli-tuksal-madem-annelik-kariyer-cocuk-basina-her-ay1500-lira-versinler-27935311 (accessed October 28, 2018).

Ayata, Ayse, and Gokten Dogangun. 2017. "Gender Politics of the AKP: Restoration of a Religio-conservative Gender Climate.”Journal of Balkan and Near Eastern Studies 19 (6): $610-27$.

Bacchi, Lee Carol. 2005. "Discourse, Discourse Everywhere: Subject 'Agency' in Feminist Discourse Methodology.” Nordic Journal of Women Studies 13 (3): 198-209.

Barbarosog lu, Fatma. 2012. "Kralic, e Victoria'nın dogum sanciları" [Queen Victoria'slabor pains]. Yeni Safak, June 6. http://www.yenisafak.com/yazarlar/fatmabarbarosoglu/ kralice-victorianin dogum-sancilari-32712 (accessed October 28, 2018).

Benford, D. Robert, and David A. Snow. 2000. "Framing Processes and Social Movements: An Overview and Assessment." Annual Review of Sociology 26 (1): 611 - 39.

Benhabib, Seyla. 1992. Situating the Self: Gender, Community and the Self in Contemporary Ethics. New York: Routledge.

Bö hü rler, Ayse. 2012. "Darbeleri Arastırma Komisyonu'nun basında iyi ki bir kadın var!" [Luckily, a woman sits as president of the commission to investigate the 15 July coup attempt]. Yeni Şafak, June 9. http://www.yenisafak.com/yazarlar/aysebohurler/darbeleri aratirma-komisyonununbainda-iyi-ki-bir-kadin-var-32751 (accessed October 28, 2018). Bora, Aksu. 2012. "Birlik ve Beraberlige en ç ok Muhtaç Oldugumuz şu Gü nlerde Kü rtaj Yasag ${ }^{\prime}$ " [The ban on abortion at a time when we need unity and solidarity most]. http://www.amargidergi.com/yeni/?p=726 (accessed October 28, 2018).

Budgeon, Shelley. 2001. "Emergent Feminist(?) Identities: Young Women and the Practice of Micropolitics.” European Journal of Women's Studies 8 (1): 7 - 28.

- - . 2015. "Individualized Femininity and Feminist Politics of Choice." European Journal of Women's Studies 22 (3): 303 - 18. 
Carastathis, Anna. 2013. "Identity Categories as Potential Coalitions." Signs: Journal of Women in Culture and Society 38 (4): $941-65$.

Cindog ${ }^{\natural}$ lu, Dilek, and Didem Unal. 2017. "Gender and Sexuality in the Authoritarian Discursive Strategies of New Turkey.” European Journal of Women's Studies 24 (1): 39-54.

Cole, Elizabeth R. 2008. "Coalitions as a Model for Intersectionality: From Practice to Theory.” Sex Roles 59 (5-6): $443-53$.

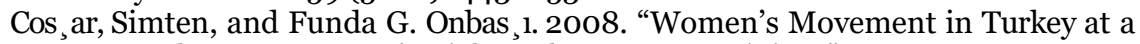
Crossroads: From Women's Rights Advocacy to Feminism.” South European Society and Politics 13 (3): $325-44$.

Cos, ar, Simten, and Metin Yeg enog $\breve{~ l u . ~ 2011 . ~ " N e w ~ G r o u n d s ~ f o r ~ P a t r i a r c h y ~ i n ~}$ Turkey? Gender Policy in the Age of AKP.” South European Society and Politics 16 (4): $555-73$.

Dean, Jodi. 1997. "Feminist Solidarity, Reflective Solidarity: Theorizing Connections after Identity Politics.” Women \& Politics 18 (4): 1- 26.

Diner, Cagla and Şule Toktaş. 2010. "Waves of Feminism in Turkey: Kemalist, Islamist and Kurdish Women's Movements in an era of Globalization." Journal of Balkan and Near Eastern Studies 12 (1): $41-57$.

Eraslan, Sibel. 2002. "Ug ultular .. . Silu"etler" [Howls and silhouettes]. In 90'larda Türkiye'de Feminizm [Feminism in 9os Turkey], eds. Aksu Bora and Asena Güldal. Istanbul: Iletis , im, 239-77.

—. 2012a. "Kürtaja Yönelten Sebeplerle Mücadele" [The struggle with factors associated with abortion]. Star, June 12. http://haber.star.com.tr/yazar/Kurtaja_ yonelten_sebeplerle_mucadele/yazi-601678 (accessed October 28, 2018).

—. 2012b. "Uç kelimede kürtaj: Cenin, cinnet ve cennet" [Abortion in three words: Fetus, insanity, and heaven]. Star, May 31. https://www.star.com.tr/yazar/Uc_ kelimede_kurtaj_Cenin_cinnet_ve_cennet-yazi-594575/(accessed November 5, 2018).

Ferree, Myra Marx. 2003. "Resonance and Radicalism: Feminist Framings in the Abortion Debates of Germany and the United States." American Journal of Sociology 109 (2): $304-44$.

2009. "Inequality, Intersectionality and Politics of Discourse: Framing Feminist Alliances." In The Discursive Politics of Gender Equality: Stretching, Bending and Policy Making, eds. Emanuela Bombardo et al. London: Routledge, 86 - 105.

Frank, Ana, and Ayșe Betül Çelik. 2017. "Beyond Islamic versus Secular Framing: A Critical Analysis of Reproductive Rights Debates in Turkey." Journal of Middle East Women's Studies 13 (2): $195-218$.

Fraser, Nancy. 2016. "Progressive Neoliberalism Versus Reactionary Populism: AChoice that Feminists Should Refuse." Nora: Nordic Journal of Feminist and Gender Research 24 (4): 281-84.

Goodwin, Jeff, and James M. Jasper. 2004. Rethinking Social Movements: Structure, Meaning, and Emotion. Lanham, MD: Rowman \& Littlefield.

Goodwin Jeff, and James M. Jasper, eds. 2011. Contention in Context: Political Opportunities and the Emergence of Protest. Stanford, CA: Stanford University Press.

Hewitt, Lyndi. 2011. "Framing across Differences, Building Solidarities: Lessons from Women's Rights Activism in Transnational Spaces." Interface: A Journal for and about Social Movements 3 (2): $65-99$.

Hürriyet. 2017. "Kadikoy'de Kiyafetime Karisma Eylemi” [Protest in Kadikoy dubbed "don’t mess with my outfit”]. July 29. http://www.hurriyet.com.tr/gundem/kadikoydekiyafetime-karisma-eylemi-40534870 (accessed November 5, 2018).

Hürriyet Daily News. 2012. “Turkish PM Vows to Pass New Abortion Law.” May 30. http:// www.hurriyetdailynews.com/turkish-pm-erdogan-vows-to-pass-new-abortion-law-21911. 
_.2013a. "Erdogan Declares Birth Control Treason.” December 22. http://www. hurriyetdailynews.com/turkish-president-erdogan-declares-birth-control-treason-75934 (accessed November 5, 2018)

- - . 2013b. "Turkish PM Reiterates His Call for Three Children.” http://www. hurriyetdailynews.com/turkishpm-erdogan-reiterates-his-call-for-three-children.aspx? pageID=238\&nid=38235 (accessed October 28, 2018).

Ilter, Balcicek. 2016. "Feminist aktivist Berrin Sönmez Habertürk'e konuștu" [Feminist activist Berrin Sonmez spoke to Habertu"rk]. Habertu" rk, May 23. http://www.haberturk. com/gundem/haber/1243350-feminist-aktivist-berrin-sonmez-haberturke-konustu (accessed October 28, 2018).

Kandiyoti, Deniz. 2016. "Locating the Politics of Gender: Patriarchy, Neo-liberal Governance and Violence in Turkey." Research and Policy on Turkey 1 (2):103-18.

Karaca, Nihal Bengisu. 2012a. "Kü rtaj ve sezaryen" [Abortion and c-section]. Habertü rk, May 30. http://www.haberturk.com/yazarlar/nihal-bengisu-karaca/746454-kurtaj-vesezaryen (accessed October 28, 2018).

—_. 2012b. "Kürtaj yasağı, kimlik ve ekonomik büyüme" [Ban on abortion, identity, and economic growth]. Habertürk, January 6. http://www.haberturk.com/yazarlar/ nihal-bengisu-karaca/747074-kurtaj-yasagikimlik-ve-ekonomik-buyume (accessed October 28, 2018).

-2012c. "Dindar kadınlardan 'Uludere'ye adalet' çagrısı” [Pious women's call for justice in Uludere]. Habertu" $r k$, June 3. https://www.haberturk.com/yazarlar/nihalbengisu-karaca/747644-dindar-kadinlardan-uludereye-adalet-cagrisi (accessed November 5,2018 ).

- 2012d. "Dogmus bir çocugun 'kürtaj' sorgusu” [An infant's inquiry about abortion]. Habertu" rk, June 8. http://www.haberturk.com/yazarlar/nihal-bengisu-karaca/749076dogmusbir-cocugunkurtaj-sorgusu (accessed October 29, 2018).

-2016. "Tasari mi Berdel mi?” [Draft bill or arranged marriage?]. Habertu" rk, November 20. http://www.haberturk.com/yazarlar/nihal-bengisu-karaca/1326175tasari-mi-berdel-mi (accessed October 28, 2018).

Keating, Cricket. 2005. "Building Coalition Consicousness.” NWSA Journal 17 (2): 86103.

Korkman, Zeynep Kurtulus. 2015. "Blessing Neoliberalism: Economy, Family, and the Occult in Millennial Turkey." Journal of the Ottoman and Turkish Studies Association 2 (2): 335-57.

-2016. "Politics of Intimacy in Turkey: A Distraction from Real Politics?" Journal of Middle East Women's Studies 12 (1): 112 - 21.

Kubilay, Çagla. 2014. "Islami Muhafazakâr Kadın Yazarların Perspektifinden Kürtaj Tartıs, masi: Eles, tirel bir Deg erlendirme" [Abortion debate from the perspective of pious women writers: A critical evaluation]. Alternatif Politika 6 (3): $387-421$.

Lugones, Maria. 2003. Pilgramages/Peregrinajes: Theorizing Coalition against Multiple Oppressions. Lanham, MD: Rowman \& Littlefield.

Lyshaug, Brenda. 2006. "Solidarity without 'Sisterhood'? Feminism and the Ethics of Coalition Building." Politics \& Gender 2 (1): 77 - 100.

Misciagno, Patricia S. 1997. Rethinking Feminist Identification: The Case for De Facto Feminism. Westport, CT: Praeger.

Moghadam, Valentine, and Elham Gheytanchi. 2010. "Political Opportunities and Strategic Choices: Comparing Feminist Campaigns in Morocco and Iran.” Mobilization: An International Journal 15 (3): 267 - 88.

Mohanty, Chandra Talpade. 2003. Feminism without Borders: Decolonizing Theory, Practicing Solidarity. Durham, NC: Duke University Press. 
Onar, Nora Fisher, and Hande Paker. 2012. "Towards Cosmopolitan Citizenship? Women's Rights in Divided Turkey." Theory and Society 41 (4): 375 - 94.

Ozcetin, Hatice. 2009. "Breaking the Silence: The Religious Muslim Women's Movement in Turkey.” Journal of International Women's Studies 11 (1): 106-19.

Ozguler, Cevahir, and Betul Yarar. 2017. "Neoliberal Body Politics: Feminist Resistance and the Abortion Law in Turkey." In Bodies in Resistance: Gender and Sexual Politics in the Age of Neoliberalism, ed. Wendy Harcourt. London: Palgrave Macmillan, 13361.

Ozinanir, Sultan. 2016. "Kadin Perspektifli bir Islami Yorumlama Bicimi Olarak Kadina Siddete Karsi Muslumanlar Insiyatifi" [Muslim initiative against violence against women as a form of Islamic interpretation from a woman's perspective]. Fe Dergi 8 (1): $118-30$.

Radikal. 2012. "Erdoğan: Sezaryene karşıyım, kürtaj bir cinayettir" [Erdoğan: I am against c-section, abortion is murder]. http://www.radikal.com.tr/politika/erdogan-sezaryenekarsiyim-kurtaj-cinayettir-1089120/ (accessed November 5, 2018).

Ramazanoğlu, Yıldız. 2012a. "Erkeklerin kürtajı” [Men’s abortion]. T24, June 13. http:// t24.com.tr/haber/kurtaj-icin-siddet-uygulayan-erkeklerden-haberiniz-varmi,206235 (accessed October 29, 2018).

-2012b. "Uludere kırılma noktamı" [Uludere is our breaking point]. Radikal, June 3. http://www.radikal.com.tr/turkiye/uludere_kirilma_noktamiz-1089937(accessed October 29, 2018).

Saktanber, Ayse, and Gül Çorbacioğlu. 2008. "Veiling and Headscarf-Skepticism in Turkey." Social Politics 15 (4): $514-38$.

Scharff, Christina. 2013. Repudiating Feminism: Young Women in a Neoliberal World. London: Ashgate.

Sehlikoglu, Sertac, . 2015. "Intimate Publics, Public Intimacies: Natural Limits, Creation and the Culture of Mahremiyet in Turkey." Cambridge Journal of Anthropology 33 (2): $77-89$.

Simga, Hulya, and Gulru Goker. 2017. "Whither Feminist Alliance? Secular Feminists and Islamist Women in Turkey.” Asian Journal of Women's Studies 23 (3): 273-93.

Şişman, Nazife. 2006. Emanetten Mülke: Kadın-Beden-Siyaset [From entrustment to property: Woman-body-politics]. Istanbul: Iz Yayıncllık.

Sonmez, Berrin. 2016. “TBMM'de Geceyarisi Tecavuz Baskini” [A midnight rape attack at the Turkish Parliament]. Gazeteduvar, November 19. https://www.gazeteduvar.com.tr/ yazarlar/2016/11/19/tbmmde-gece-yarisi-tecavuzbaskini/ (accessed October 29, 2018).

Sutton, Barbara, and Elizabeth Borland. 2013. "Framing Abortion Rights in Argentina's Encuentros Nacionales de Mujeres.” Feminist Studies 39 (1): 194-234.

Taraf. 2012. "Allah cenini kadına emanet etti" [God entrusted the fetus to women]. June 5.

Tuksal, Hidayet Șefkatli. 2012a. "Her çocuk için maaş verin, sonra üç çocuk isteyin" [First providechild support, then askfor threechildren]. Aksam,June6.http://www.aksam.com. tr/guncel/her-cocuk-icin-maas-verin,-sonra-ucisteyin-119841h/haber-119841 (accessed October 28, 2018).

-2012b. "Uludere'dekurtajyok, c,ocuk cesetlerivar" [Uludere is not about abortion, it is about children's dead bodies]. Radikal, June 6. http://www.radikal.com.tr/turkiye/ uluderede_kurtaj_yok_cocuk_cesetleri_var-1090283 (accessed October 28, 2018).

Unal, Didem. 2015. "Vulnerable Identities: Pious Women Columnists' Narratives on Islamic Feminism and Feminist Self-I dentification in Contemporary Turkey." Women's Studies International Forum 53: 12 - 21.

Unal, Didem, and Dilek Cindog lu. 2013. "Reproductive Citizenship in Turkey: Abortion Chronicles.” Women's Studies International Forum 38: 21 - 31. 
Verloo, Mieke. 2013. "Intersectional and Cross-movement Politics and Policies: Reflections on Current Practices and Debates." Signs 38 (4): 893-915.

Weir, Allison. 2008. "Global Feminism and Transformative Identity Politics." Hypatia 23 (4): $110-33$.

Whittier, Nancy. 2014. "Rethinking Coalitions: Anti-pornography feminists, Conservatives and Relationships between Collaborative Adversarial Movements." Social Problems 61 (2): $175-93$.

.2018. Frenemies: Feminists, Conservatives and Sexual Violence. Oxford: Oxford University Press.

Yazıcı, Berna. 2012. "The Return to the Family: Welfare, State and Politics of the Family in Turkey." Anthropological Quarterly 85 (1): 103-40. 